\title{
Functional Integration of Calcium Regulatory Mechanisms at Purkinje Neuron Synapses
}

\author{
Ruth M. Empson • Thomas Knöpfel
}

Published online: 2 July 2010

(C) The Author(s) 2010. This article is published with open access at Springerlink.com

\begin{abstract}
Cerebellar Purkinje neurons receive synaptic inputs from three different sources: the excitatory parallel fibre and climbing fibre synapses as well as the inhibitory synapses from molecular layer stellate and basket cells. These three synaptic systems use distinct mechanisms in order to generate $\mathrm{Ca}^{2+}$ signals that are specialized for specific modes of neurotransmitter release and postsynaptic signal integration. In this review, we first describe the repertoire of $\mathrm{Ca}^{2+}$ regulatory mechanisms that generate and regulate the amplitude and timing of $\mathrm{Ca}^{2+}$ fluxes during synaptic transmission and then explore how these mechanisms interact to generate the unique functional properties of each of the Purkinje neuron synapses.
\end{abstract}

Keywords Functional integration .

Calcium regulatory mechanisms $\cdot$ Purkinje neuron

\section{Overview}

Chemical synaptic communication critically depends on specific calcium ion $\left(\mathrm{Ca}^{2+}\right)$ signals on both sides of the synapse. The plasma membranes of the pre- and postsynaptic cellular compartments provide a diffusion barrier

\footnotetext{
R. M. Empson Dunedin, New Zealand

T. Knöpfel $(\square)$

Laboratory for Neuronal Circuit Dynamics,

RIKEN Brain Science Institute,

Wako-shi,

Saitama 351-0198, Japan

e-mail: tknopfel@brain.riken.jp
}

Department of Physiology, Brain Health and Repair Research Centre, University of Otago School of Medical Sciences, between the high $\mathrm{Ca}^{2+}$ concentration $\left(\left[\mathrm{Ca}^{2+}\right]\right)$ in the extracellular space $(\sim 1 \mathrm{mM}$ range $)$ and the low resting cytosolic $\left[\mathrm{Ca}^{2+}\right]$ ( 20 to $\left.50 \mathrm{nM}[1]\right)$. The plasma membranes of these compartments contain the $\mathrm{Ca}^{2+}$ regulatory mechanisms specialized to control passive, "down the gradient," or active, and energy consuming "against the gradient," trans-membrane $\mathrm{Ca}^{2+}$ fluxes. Cerebellar Purkinje neurons (PNs) are a well studied and instructive example of a neuron that receives a variety of different synaptic inputs with distinct properties, all of which influence cerebellar function. In this review, we will explore how the different available $\mathrm{Ca}^{2+}$ regulatory mechanisms influence the unique properties of these different types of PN synapses.

Each of the approximately hundred thousand synapses formed with every PN in the mammalian cerebellum is a hotspot of chemical communication that relies on $\mathrm{Ca}^{2+}$ dependent events. Pre-synaptic $\mathrm{Ca}^{2+}$ initiates neurotransmitter release [2], while $\mathrm{Ca}^{2+}$ has several functions at the post-synaptic membrane. Being a charge carrier, $\mathrm{Ca}^{2+}$ flux across the PN membrane generates a depolarizing inward current that contributes directly to the electrical responsiveness of the post-synaptic neuron. Furthermore, $\mathrm{Ca}^{2+}$ influx exerts indirect effects on the electrical behaviour of the neuron by activating $\mathrm{Ca}^{2+}$-dependent outward currents (carried by $\mathrm{Ca}^{2+}$-dependent $\mathrm{K}^{+}$channels and discussed in more detail by Anwar et al., in the accompanying review). In addition to these immediate ("real time") actions, $\mathrm{Ca}^{2+}$ also acts as a chemical messenger to initiate changes in long-term synaptic efficacy, where the amplitude, dynamics, and location of the $\mathrm{Ca}^{2+}$ signal can influence whether the synapses strengthen or weaken (discussed in more detail by Finch and Augustine, in the accompanying review).

Here, we aim first to describe the repertoire of $\mathrm{Ca}^{2+}$ regulatory mechanisms that generate and regulate the amplitude and timing of $\mathrm{Ca}^{2+}$ fluxes during synaptic 
transmission (the " $\mathrm{Ca}^{2+}$ toolbox"). After describing how these basic mechanisms act in isolation, we will then explore how they interact to generate the unique functional properties of the following important PN synapses; the excitatory parallel fibre (PF) and climbing fibre (CF) synapses as well as the inhibitory synapses (IS) from molecular layer stellate and basket cells (see Fig. 1).

\section{The Components of the $\mathrm{Ca}^{2+}$ Toolbox at Cerebellar Synapses}

The Plasma Membrane

As the main barrier to external high $\left[\mathrm{Ca}^{2+}\right]$, the components of the $\mathrm{Ca}^{2+}$ toolkit that reside within the pre- and postsynaptic plasma membranes are critical for providing controlled entry and extrusion of $\mathrm{Ca}^{2+}$.

\section{Voltage-Gated $\mathrm{Ca}^{2+}$ Channels}

Voltage-gated $\mathrm{Ca}^{2+}$ channels (VGCC) are the route for practically all $\mathrm{Ca}^{2+}$ entering the pre-synaptic and postsynaptic compartments of PNs (reviewed also in [3]). VGCCs can be separated into the high-voltage activated channels (HVA), L-type, P/Q-type, and N-type channels and the low-voltage activated channels, or T-type. The HVA channels consist of the ion channel alphal subunit accompanied by the accessory alpha2delta and beta subunits to create functional and highly modifiable channels (for a review see [4]). Functional diversity of HVA channels arises through differences in the alphal subunit sequence to generate four main families of channels (Table 1). The PN richly expresses $\mathrm{P} / \mathrm{Q}$ (alpha 1A; Cav2.1) type channels, called this following their first discovery in PNs [5] where, in contrast to a wide variety of other neurons, they are abundant in the post-synaptic dendrites $[6,7]$. These $\mathrm{P} / \mathrm{Q}$ channels contribute most to the PN's HVA $\mathrm{Ca}^{2+}$ current, and although some dihydropyridine-sensitive L-type current (mediated by alpha 1C; Cav1.2) also contribute to this, there is little contribution from fast N-type currents (alpha 1B; Cav2.2) [8].There is some evidence for functional expression of Rtype channels (alpha 1E subunit containing; Cav2.3) [9], particularly their contribution with T-type channels to the low threshold $\mathrm{PN} \mathrm{Ca}^{2+}$ spike [10].

While opening these channels provides the major route for $\mathrm{Ca}^{2+}$ flux across the plasma membranes of the pre- and post-synaptic sites, the amount of $\mathrm{Ca}^{2+}$ entry is also controlled by the kinetics of channel activation and inactivation. The rich contribution from the fast-activating and rapidly inactivating $\mathrm{P} / \mathrm{Q}$ channels in the $\mathrm{PN}$ dendrites

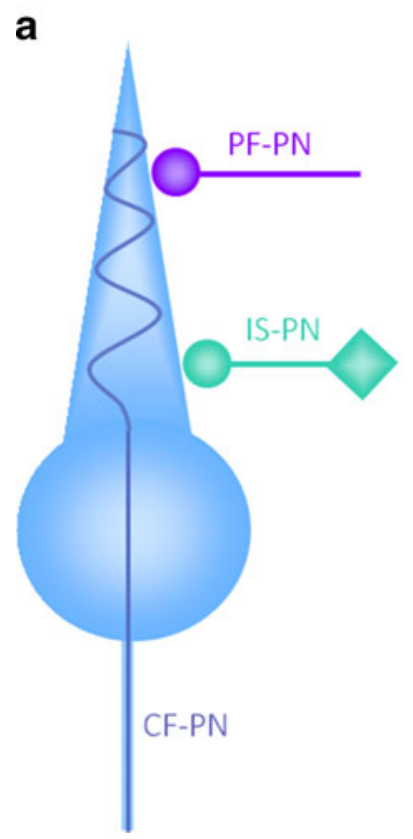

Fig. 1. a Schematic of a cerebellar Purkinje neuron $(P N, b l u e)$ with its main synapses, the excitatory climbing fibre input from the inferior olive $(C F-P N, r e d)$, the excitatory parallel fibre input from the cerebellar granule cells ( $P F-P N$, light red), and the inhibitory synapses (IS-PN, green) from the stellate and basket cell inhibitory interneurones. b Calcium regulatory mechanisms within the different synapse compartments are shown; colours correspond to the colour used for
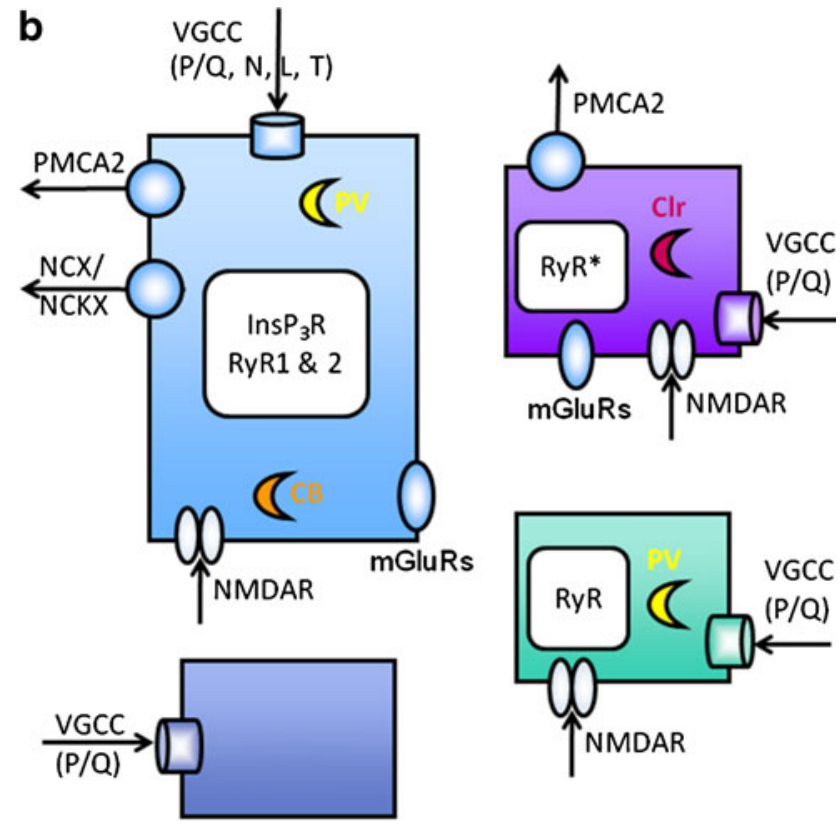

the different synapses in a. $V G C C$ voltage-gated calcium channel, $P M C A$ plasma membrane calcium ATPase, NCX sodium calcium exchanger, $N C K X$ sodium calcium potassium dependent exchanger, $R y R$ ryanodine receptor, Ins $P_{3}-R$ inositol trisphosphate receptor, $N M D A-R N$-methyl-D-aspartate receptor, $m G l u R$ metabotropic glutamate receptor sub-type, $C B$ calbindin, $P V$ parvalbumin, $C l r$ calretinin 
Table 1 Variety of sub-types of the alpha1 subunit of voltage-gated calcium channels expressed and functional at cerebellar PN synapses

\begin{tabular}{|c|c|c|c|c|c|}
\hline$\alpha 1$ subunit & PC soma & PC dendrite & CF terminal & PF terminal & inhibitory \\
\hline Cav2.1 (P-type) & $90 \%[6]$ & $90 \%[6]$ & $70 \%[47,61]$ & Major [47] & $\begin{array}{l}\text { No [47] but see } \\
\text { also [64] }\end{array}$ \\
\hline Cav2.2 (N-type) & - & - & $30 \%[47,61]$ & $\begin{array}{l}\text { Expressed, but less } \\
\text { than P-type [47] }\end{array}$ & No [47] \\
\hline Cav3.1 (T-type) & $5 \%$ Cav3.3 $[91]$ & $\sim 5 \%$ [91] Cav3.1 spine Cav3.3 shaft & Absent & Absent & \\
\hline Cav1.x (L-type) & Minor [8] & Minor [8] & NS & NS & NS \\
\hline
\end{tabular}

Percentage values are estimated contributions to total calcium currents NS non significant

provides for sharp $\mathrm{Ca}^{2+}$ transients and contrasts with the slower and more prolonged $\mathrm{Ca}^{2+}$ entry that accompanies the opening of L-type VGCCs in other neurons. The reliance on $\mathrm{P} / \mathrm{Q}$ type channels and paucity of $\mathrm{N}$-type channels may provide a degree of signalling simplicity in the PN dendrite. Opening of both types of channels is not only controlled by membrane voltage but also through interaction with $\mathrm{Ca}^{2+}$-sensing proteins such as calmodulin [11]. The details of these interactions differ between the channel types but their general effect is to limit further $\mathrm{Ca}^{2+}$ entry when calcium rises to a certain level. Furthermore, both types of channels can be modulated by the activation of a variety of G-protein-coupled receptors, influencing both their open kinetics and their insertion into membranes.

\section{$\mathrm{Ca}^{2+}$ Pumps and Exchangers}

$\mathrm{Ca}^{2+}$ influx is balanced by mechanisms that return, or extrude, $\mathrm{Ca}^{2+}$ to the extracellular space (or to intracellular compartments, see below "Pre-Synaptic $\mathrm{Ca}^{2+}$ Control Mechanisms"). On the long term, the net balance of $\mathrm{Ca}^{2+}$ influx and efflux has to be zero in order to maintain low intracellular $\left[\mathrm{Ca}^{2+}\right]$. Influx can however exceed efflux on a time scale faster than a few seconds to cause a transient rise in intracellular $\left[\mathrm{Ca}^{2+}\right]$ $\left(\mathrm{Ca}^{2+}\right.$ transients). The main routes for $\mathrm{Ca}^{2+}$ efflux across the plasma membrane are via the plasma membrane $\mathrm{Ca}^{2+}$ ATPase (PMCA), often called the $\mathrm{Ca}^{2+}$ pump, and the sodium $\left(\mathrm{Na}^{+}\right) \mathrm{Ca}^{2+}$ exchangers (NCX and NCKX). These $\mathrm{Ca}^{2+}$ regulatory mechanisms transport $\mathrm{Ca}^{2+}$ against their concentration gradient from the cytosol into the extracellular space using energy obtained directly from ATP, in the case of the pump, or indirectly using the $\mathrm{Na}^{+}$gradient, in the case of the exchangers.

All four PMCA isoforms (1-4) are present in the cerebellum, but PMCA2 is the most highly expressed [12]. PMCA2 is expressed throughout the cerebellar cortex where it is enriched in the molecular layer and the PN soma, dendrites, and dendritic spines [13]. Activation of PMCAs most often requires the binding of $\mathrm{Ca}^{2+}$ to the high-affinity $\mathrm{Ca}^{2+}$ sensing protein calmodulin. $\mathrm{Ca}^{2+}$ calmodulin then binds to the PMCA and relieves the intrinsic autoinhibition resident within its C-terminal tail. At physiological levels of calmodulin (up to micromolar levels in neurons), the apparent affinity $\left(k_{0.5}\right)$ of PMCA2 for $\mathrm{Ca}^{2+}$ is $60 \mathrm{nM}$, close to resting $\left[\mathrm{Ca}^{2+}\right]$ in the $\mathrm{PN}$. This means that $\mathrm{Ca}^{2+}$ transport by PMCA2 can adjust even small fluctuations in cytosolic $\left[\mathrm{Ca}^{2+}\right]$ [14]. A faster response to changes in $\left[\mathrm{Ca}^{2+}\right]$ is achieved by PMCA2a, the shortened splice form of PMCA2 that lacks the full calmodulin-binding site. With an apparent rate constant for activation of $0.07 \mathrm{~s}^{-1}$ (in the presence of $500 \mathrm{nM} \mathrm{Ca}^{2+}$ ) PMCA2a is one of the fastest activating PMCA $\mathrm{Ca}^{2+}$ transporters [15]. Interestingly, this splice variant is highly expressed in PN spines and dendrites [16].

The other major active $\mathrm{Ca}^{2+}$ transporter located at the plasma membrane is the $\mathrm{Na}^{+} / \mathrm{Ca}^{2+}$ exchanger (NCX), also highly expressed in the cerebellum. Isoforms NCX 1 and 3 are expressed in the cerebellar cortex in both granule cell and molecular layers and at pre- and post-synaptic membranes [17]. NCX exchanges three $\mathrm{Na}^{+}$for one $\mathrm{Ca}^{2+}$, and the direction of $\mathrm{Ca}^{2+}$ flux depends on the relative electrochemical driving force of the $\mathrm{Na}^{+}$and $\mathrm{Ca}^{2+}$ gradients. Working in its forward mode, the exchanger utilizes the inward $\mathrm{Na}^{+}$ gradient to extrude $\mathrm{Ca}^{2+}$ to the extracellular space. Unlike the PMCA, activation of NCX mediated $\mathrm{Ca}^{2+}$ efflux does not require calmodulin. Instead, intracellular $\mathrm{Ca}^{2+}$ (and $\mathrm{Na}^{+}$) binds to and activates the exchanger directly. Furthermore, the apparent affinity of $\mathrm{Ca}^{2+}$ binding $\left(k_{0.5}\right)$ changes with internal $\left[\mathrm{Ca}^{2+}\right]$. At $500 \mathrm{nM}\left[\mathrm{Ca}^{2+}\right], k_{0.5}$ of the exchanger's efflux activity in the squid giant axon is $22 \mu \mathrm{M}$ [18], an approximately 500-fold lower apparent affinity for $\mathrm{Ca}^{2+}$ than PMCA2. Under conditions where the $\mathrm{Na}^{+}$gradient is weakened (that is when intracellular $\mathrm{Na}^{+}$is high), the NCX exchanger works in reverse mode to extrude $\mathrm{Na}^{+}$and accumulate cytosolic $\mathrm{Ca}^{2+}[19]$. In contrast, the $\mathrm{Na}^{+}-\mathrm{Ca}^{2+}$ potassium $\left(\mathrm{K}^{+}\right)$exchanger $(\mathrm{NCKX})$, normally works in reverse mode to bring $\mathrm{Ca}^{2+}$ into cells but will work in forward mode as a $\mathrm{Ca}^{2+}$ extrusion mechanism when intracellular $\left[\mathrm{Ca}^{2+}\right]$ is $>300 \mu \mathrm{M}$. Furthermore, the forward mode of NCKX2 exhibits faster kinetics than the reverse (influx) mode [20]. NCKX is functional in cerebellar granule 
cells [21], so it is possible that this $\mathrm{Ca}^{2+}$ extrusion mechanism contributes to $\mathrm{Ca}^{2+}$ dynamics at the PF-PN synapse under certain conditions.

All together, these very different mechanisms provide for well-regulated $\mathrm{Ca}^{2+}$ efflux over a range of $\left[\mathrm{Ca}^{2+}\right]$ at cerebellar synapses. We predict that the PMCA2 pump will be readily recruited by small fluctuations in intracellular $\mathrm{Ca}^{2+}$ but that, during larger intracellular $\mathrm{Ca}^{2+}$ excursions, when PMCA becomes saturated, $\mathrm{Ca}^{2+}$ efflux can continue via the NCX and possibly even the NCKX. However, the relative contribution of PMCA, NCX, and NCKX at the different compartments of cerebellar synapses and under different functional conditions is yet to be determined (see also below).

\section{The Cytosol}

\section{$\mathrm{Ca}^{2+}$ Buffers}

Cytosolic proteins that bind $\mathrm{Ca}^{2+}$ in the physiological $\left[\mathrm{Ca}^{2+}\right]$ range and are expressed at concentrations of hundreds of micro- or millimolars can act as $\mathrm{Ca}^{2+}$ buffers. The prominent $\mathrm{Ca}^{2+}$ buffers expressed within the cerebellum are calretinin, calbindin, and parvalbumin, the latter two both richly expressed within the PN cytosol [22,] whereas inhibitory stellate and basket cells only express parvalbumin. Calretinin, expressed by granule cells and therefore present in the pre-synaptic PF terminals [23], has the fastest apparent $\mathrm{Ca}^{2+}$ binding kinetics of $>>10^{8} \mathrm{~s}^{-1}$ and is often referred to as a "fast buffer." The $\mathrm{Ca}^{2+}$-binding kinetics of calbindin and parvalbumin are rather slower (but see also "Climbing Fiber Post-Synapse: CF Stimulation Leads to a Very Large PostSynaptic Dendritic $\left[\mathrm{Ca}^{2+}\right]$ Signal That Is Heavily Influenced by a Variety of $\mathrm{Ca}^{2+}$ Regulatory Mechanisms"). All three of the $\mathrm{Ca}^{2+}$ buffers express multiple copies of the EF hand $\mathrm{Ca}^{2+}$ binding motif and have an affinity for $\mathrm{Ca}^{2+}$ between $10 \mathrm{nM}$ and $10 \mu \mathrm{M}$ [24]. $\mathrm{Ca}^{2+}$ buffers have the capacity to efficiently dampen the effect of short-lasting but massive $\mathrm{Ca}^{2+}$ influx (that is a smaller rise in free $\left[\mathrm{Ca}^{2+}\right]$ than expected from the actual amount of $\mathrm{Ca}^{2+}$ influx). Their limitation is that they can be saturated, or overwhelmed, during prolonged periods of strong $\mathrm{Ca}^{2+}$ influx, but the extent to which this occurs depends upon their expression levels. Interestingly, $\mathrm{Ca}^{2+}$ buffer expression and hence buffer capacity increases during cerebellar development [25]. Conversely, PN calbindin levels decrease during aging [26] and also before the onset of cerebellar ataxia [27], perhaps in the latter case as a pretext to cell death as occurs in several forms of human ataxias.

\section{Intracellular, $\mathrm{ER} \mathrm{Ca}^{2+}$ "Stores"}

In addition to binding of $\mathrm{Ca}^{2+}$ by buffers, $\mathrm{Ca}^{2+}$ can also be removed from the cytosol by uptake (sequestration) into intracellular organelles. The major organelle used for this purpose in neurons is the endoplasmic reticulum (ER) where $\mathrm{Ca}^{2+}$ is bound to proteins such as calsequestrin within the lumen [28]. Specific mechanisms also allow $\mathrm{Ca}^{2+}$ in the ER to be mobilized (returned to the cytosol) so that the ER provides bidirectional control of $\mathrm{Ca}^{2+}$ dynamics: either to provide extra cytosolic $\left[\mathrm{Ca}^{2+}\right]$ or to act as a sink for excessive cytosolic $\left[\mathrm{Ca}^{2+}\right] \mathrm{Ca}^{2+}$ uptake into the ER is driven by the sarcoplasmic/endoplasmic reticulum $\mathrm{Ca}^{2+}$ ATPase (SERCA), another family of $\mathrm{Ca}^{2+}$ ATPase pump that exists as a variety of isoforms in the cerebellum. This protein shares significant homology with the PMCA, although SERCA2b's apparent affinity, $k_{0.5}$, for $\mathrm{Ca}^{2+}$ is approximately $300 \mathrm{nM}$, rather higher than PMCA2 (see above). SERCAs [29], like the PMCAs, also have a fast apparent rate constant for activation by $\mathrm{Ca}^{2+}$ (see above discussion on fast PMCA2a, " $\mathrm{Ca}^{2+}$ Pumps and Exchangers"). The SERCA isoform 2 is widely distributed in the cerebellum [30], and more recently, SERCA has been localized to the PNs, the molecular layer interneurons, and also in pre- and postsynaptic structures [31]. The SERCA 3 isoform, which invariably co-expresses with the SERCA2b isoform [32], is also enriched within PNs [33]. SERCA3's lower apparent affinity for $\mathrm{Ca}^{2+}\left(k_{0.5}=\right.$ approximately $\left.1 \mu \mathrm{M}\right)[32]$ is predicted to enable $\mathrm{Ca}^{2+}$ uptake into the ER during very large excursions in cytosolic $\left[\mathrm{Ca}^{2+}\right]$. Indeed, pharmacological studies showed that SERCA makes the largest contribution to somatic $\left[\mathrm{Ca}^{2+}\right]$ recovery following a massive $\mathrm{PN}$ depolarization [34], making SERCA effective at $\left[\mathrm{Ca}^{2+}\right]$ concentrations ranging between that of $\mathrm{Ca}^{2+}$ buffer binding and the activation of NCX (see above), with a contribution exceeding that of PMCA, at least at high, peak $\left[\mathrm{Ca}^{2+}\right]$ in the PN soma.

When loaded with $\mathrm{Ca}^{2+}$, the ER store can provide $\mathrm{Ca}^{2+}$ to amplify the effect of $\mathrm{Ca}^{2+}$ influx. The mechanism is called $\mathrm{Ca}^{2+}$-induced $\mathrm{Ca}^{2+}$ release (CICR) and is triggered by cytosolic $\mathrm{Ca}^{2+}$ and mediated by ryanodine (Ry) or inositol trisphosphate $\left(\mathrm{InsP}_{3}\right)$-sensitive channels in the ER membrane. In addition to CICR, $\mathrm{Ca}^{2+}$ can be mobilized from filled ER stores by high concentrations of $\mathrm{InsP}_{3}$ generated in the cytosol following activation of metabotropic glutamate receptors (sub-type 1, mGluR1). These Gprotein-coupled receptors are expressed at very high levels in PN dendrites. Both $\mathrm{a}$ and $\mathrm{b}$ mGluR1 splice variants (mGluR1a and mGluR1b) are localized in the post-synaptic membrane around PF synapses (peri-synaptic localization) and at extra-synaptic sites [35]. This localization explains the requirement of pooling and spillover of synaptically released glutamate to activate mGluR1 [36].

The PNs are unique among neurons, as they express the skeletal muscle type of ryanodine channel/receptor, RyR1 [37], while most other neurons (including the PN) express the cardiac isoform RyR2 [38]. While RyR1 mediates direct 
depolarisation-induced $\mathrm{Ca}^{2+}$ release [39] from the sarcoplasmic reticulum, as occurring at the skeletal muscle triad, there is no physiological evidence to indicate that this direct excitation-coupling occurs in PNs [40]. PNs also express some of the highest levels of the type $1 \mathrm{InsP}_{3}$ receptor in the central nervous system [41, 42].

In the PN, both InsP $\mathrm{P}_{3} \mathrm{Rs}$ and RyRs seem to access the same intracellular $\mathrm{Ca}^{2+}$ pool [43], although removal of $\mathrm{InsP}_{3}$ type 1 receptors from $\mathrm{PNs}$ in $\mathrm{InsP}_{3}-1$ knockout mice had little effect upon the magnitude of PN CICR activated by caffeine [44].

Regardless of the route, the effectiveness and contribution of the ER to pre- and post-synaptic transmission, whether behaving as a sink or a source of $\mathrm{Ca}^{2+}$, will clearly depend upon a variety of factors, such as the fill state, the balance between release and refilling during synaptic activity and the kinetics of the different $\mathrm{Ca}^{2+}$ release channels. For example, important questions remain as to whether the ER is primed to release or take up $\mathrm{Ca}^{2+}$ in different states and whether the store state under these conditions varies between the different synapses in the cerebellum.

While our summary of the $\mathrm{Ca}^{2+}$ regulatory mechanisms that operate in the cerebellum is not complete, we have covered the key components required to understand how the integration of these mechanisms contributes to cerebellar synapse function. In the following paragraphs, we will explore how these mechanisms work together to provide flexible-controlled generation of pre- and post-synaptic $\mathrm{Ca}^{2+}$ transients for effective neurotransmission at $\mathrm{PN}$ synapses.

\section{Pre-synaptic $\mathrm{Ca}^{2+}$ Control Mechanisms}

\section{Excitatory PF Pre-synapse: At this Low Release Probability Synapse, Small and Accumulating $\mathrm{Ca}^{2+}$ Signals are Fine-Tuned by $\mathrm{Ca}^{2+}$ Regulatory Mechanisms to Control Pre-synaptic $\mathrm{Ca}^{2+}$ Transients and Transmitter Release}

Entry of $\mathrm{Ca}^{2+}$ into pre-synaptic $\mathrm{PF}$ terminals occurs primarily through highly expressed P/Q-type (Cav2.1) channels [7], since omega-Aga-IVA toxin has the greatest inhibitory effect upon synaptic transmission at this synapse. However, N-type (Cav2.2) as well as possibly R-type (Cav2.3) VGCCs also make a contribution [45-47].

The PF input to the PN is a low release probability synapse, but release probability increases (facilitates) for a short period following initial activation. This phenomenon is termed paired pulse facilitation (or frequency facilitation in the case of repetitive activity) and has been explained by the effect of residual pre-synaptic $\left[\mathrm{Ca}^{2+}\right]$ that adds to the second response in a paired stimulation paradigm [48]. Release probability and frequency facilitation are directly related to the amplitude and decay rate of the pre-synaptic $\left[\mathrm{Ca}^{2+}\right]$ transient. The amplitude of the $\mathrm{Ca}^{2+}$ signal is directly regulated by pre-synaptic auto- and heteroreceptors (GABAB, cannabinoid, $\mathrm{CB} 1$, and mGluR4), acting on pre-synaptic VGCCs $[49,50]$. The control of the decay of the pre-synaptic $\left[\mathrm{Ca}^{2+}\right]$ transient, and hence the amount of residual pre-synaptic $\mathrm{Ca}^{2+}$, falls to $\mathrm{Ca}^{2+}$ extrusion mechanisms [51] and $\mathrm{Ca}^{2+}$ buffers [52, 53]. Somewhat surprisingly, the behaviour of paired pulse facilitation at the PF-PN synapse was not significantly altered in the calretinin knockout mouse even though the mice exhibit a lack of motor coordination when challenged [54]. A possible reason for this may lie in the relatively small contribution from calretinin alone as an endogenous buffer during a paired pulse stimulation paradigm. More recently, a rather heterogeneous distribution of buffer capacity within individual PF boutons has been shown [55] and may arise through different expression levels of endogenous $\mathrm{Ca}^{2+}$ buffers between and possibly even within boutons. As yet, the contribution of factors that influence buffer capacity of individual PF boutons are not fully understood, despite the fact that their relative contributions will influence the release properties and facilitation of this important pre-synaptic compartment (see also below). Most recently, heterogeneity of individual $\left[\mathrm{Ca}^{2+}\right]$ transients in $\mathrm{PF}$ pre-synaptic boutons was ascribed to differences in presynaptic action of auto- and hetero-receptors [56].

Physiological evidence indicates that $\mathrm{Ca}^{2+}$ extrusion via PMCA2 normally shapes the decay of the pre-synaptic PF $\left[\mathrm{Ca}^{2+}\right]$ transient since the rate of $\left[\mathrm{Ca}^{2+}\right]$ recovery is delayed in PFs of PMCA2 knockout mice [51]. Furthermore, this slowed recovery in the PMCA2 PFs is expressed as a prolongation of paired pulse facilitation at this synapse. This indicates that an accumulation of residual $\left[\mathrm{Ca}^{2+}\right]$ is enhanced in the absence of PMCA2. Modelling studies [57] also indicate that NCX may play a similar role, but this has not been experimentally tested to date. It remains possible that some of the heterogeneity between individual PF boutons arises from different expression levels and even types of $\mathrm{Ca}^{2+}$ extrusion mechanisms (PMCA vs NCX isoforms, see above, " $\mathrm{Ca}^{2+}$ Pumps and Exchangers")

The ER $\mathrm{Ca}^{2+}$ stores seem to play very little, if any, part in the control of PF pre-synaptic $\left[\mathrm{Ca}^{2+}\right]$ under physiological conditions, as revealed by the lack of sensitivity of paired pulse facilitation to thapsigargin (a SERCA inhibitor that empties ER stores) at this synapse [58]. This finding is consistent with the idea that release of $\mathrm{Ca}^{2+}$ from the stores is really only needed when amplification of the $\left[\mathrm{Ca}^{2+}\right]$ is necessary. Presumably, given the low release probability of the PF-PN synapse, additional amplification of pre-synaptic $\left[\mathrm{Ca}^{2+}\right]$ is not needed since accumulation is sufficient. It is even possible that restricted space within the small volume of the PF terminal might preclude the participation of the stores, although more recently, a contribution from Rysensitive $\mathrm{Ca}^{2+}$ stores to mGluR-dependent alterations of 
release probability at mature PF synapses has been described [59]. This raises the possibility that, under special circumstances, ER $\mathrm{Ca}^{2+}$ stores can contribute to the facilitatory properties of PFs.

\section{Excitatory CF Pre-synapse: Where $\mathrm{Ca}^{2+}$ Dynamics} in the Pre-synapse are Dominated by $\mathrm{Ca}^{2+}$ Influx to Ensure Reliable Transmission

The importance of the CF input to the PNs is reflected by its strength and reliability. The high probability of glutamate release at each of numerous release sites [60] distributed over a very large area of PN dendrite ensures that there is no synaptic failure.

At the CF pre-synapse, the specific toxin omega-AgaIVA largely reduces the synaptic response, indicating the importance of P/Q-type VGCCs, although N-type channels also contribute to this reduction $[47,61]$. The $\left[\mathrm{Ca}^{2+}\right]$ transient in the CF pre-synaptic compartment has not been systematically measured, but the high release probability of the synapse suggests that $\mathrm{Ca}^{2+}$ influx will dominate. We anticipate that during high frequency repetitive stimulation of the $\mathrm{CF}$, accumulation of $\mathrm{Ca}^{2+}$ occurs but that depletion of vesicles dictates that synapse strength decreases (exhibits paired-pulse depression). The paucity of literature on the $\left[\mathrm{Ca}^{2+}\right]$ dynamics within the CF pre-synaptic compartment is presumably because the behaviour of this synapse is dominated by the anatomical specialisation of its release machinery. We could predict, however, that the CF presynapse may behave rather similarly to the calyx of Held, another high release probability, depressing synapse where repetitive stimulation leads to an increase in the amplitude of the pre-synaptic $\mathrm{Ca}^{2+}$ transient per action potential (presumably via accumulation) even as the post-synaptic response decreases [62].

Inhibitory Basket Cell Pre-synapse: Here, the Pre-synaptic $\left[\mathrm{Ca}^{2+}\right]$ Transient is Dominated by Amplification of $\left[\mathrm{Ca}^{2+}\right]$ via Release from Intracellular Stores Resulting in a High Transmitter Release Probability

Like the CF-PN synapse, the release of GABA from basket/ stellate cells onto PNs is a high release probability synapse [63], reflecting the importance of feed forward synaptic inhibition at the granule cell to PN pathway for cerebellar function.

$\mathrm{Ca}^{2+}$ entry into the GABA-ergic pre-synaptic terminals uses P/Q-type (Cav2.1) channels present on GABA-ergic stellate and basket cell terminals within the molecular layer of mouse cerebellar cortex. Opening of these channels is required for GABA release, as determined by the sensitivity of PN spontaneous GABA-mediated inhibitory postsynaptic currents (IPSCs) to $200 \mathrm{nM}$ omega-Aga-IVA ([64]; but see also [65], and below). However, there is little or no contribution from N-, R-, or T-type (Cav3.1) VGCCs to GABA release from stellate and basket cell terminals (but see also [47]). More recently, NMDA receptor-mediated $\mathrm{Ca}^{2+}$ influx and depolarisation of stellate cell dendrites has been shown to release GABA from stellate cell axon varicosities [66]. In contrast, brief activation of AMPA receptors by glutamate suppresses $\mathrm{Ca}^{2+}$ entry by acting at pre-synaptic VGCCs on the basket cell terminals [67].

Measurements of $\mathrm{Ca}^{2+}$ transients in the large basket cell axonal varicosities during GABAergic transmission revealed large spontaneous $\left[\mathrm{Ca}^{2+}\right]$ transients (SCaTs) coincident [65] with the giant IPSCs in the PNs. These events persist in the absence of pre-synaptic action potentials [68] and are driven by very large excursions in $\left[\mathrm{Ca}^{2+}\right]$ amplified by additional $\mathrm{Ca}^{2+}$ released from RyRsensitive $\mathrm{ER} \mathrm{Ca}^{2+}$ stores [65]. By utilizing $\mathrm{Ca}^{2+}$ from ER stores in this way, the synapse is able to generate the size of $\mathrm{Ca}^{2+}$ signal that is required. Presumably, the large size of the varicosity means that stores of sufficient capacity can also be accommodated. We predict that the fill state of the ER stores should influence the amplitude and distribution of SCaTs, but whether these ER stores can also act as a sink for $\left[\mathrm{Ca}^{2+}\right]$ is not known. Moreover, at this synapse, the SCaTs persisted in the presence of a high concentration of the $\mathrm{P} / \mathrm{Q} / \mathrm{N}$-type $\mathrm{Ca}^{2+}$ channel antagonist, omega-conotoxin MVIIC, suggesting that $\mathrm{Ca}^{2+}$ influx through VGCC is not required as a trigger [65]. Nevertheless, other pre-synaptic receptors may provide additional ways to modify $\left[\mathrm{Ca}^{2+}\right]$ dynamics at this synapse [69].

More recently, coupling between activation of glutamate operated pre-synaptic NMDA receptors and RyR-sensitive ER stores at basket cell terminals has been shown during depolarisation-induced potentiation of inhibition. In this mode, $\left[\mathrm{Ca}^{2+}\right]$ elevation in the $\mathrm{PN}$ drives retrograde activation of pre-synaptic NMDA receptors to elevate $\left[\mathrm{Ca}^{2+}\right]$ in the pre-synaptic terminal through release from intracellular stores [70].

The main mechanism that limits the large rises in $\left[\mathrm{Ca}^{2+}\right]$ in these pre-synaptic terminals is endogenous $\mathrm{Ca}^{2+}$ buffers. The basket and stellate cells express high concentrations of parvalbumin (PV) to ensure a very high endogenous $\mathrm{Ca}^{2+}$ buffer capacity. The high action potential firing frequency that is typical for basket cells may well demand this. Indeed, $\mathrm{PV}$ is known to be required for the control of release probability at the basket cell to PN synapse; without PV in $\mathrm{PV}^{-1-}$ mice, the synapse switches from being a high release probability depressing synapse to a facilitating one [71]. PV is also critical for shaping the pre-synaptic $\mathrm{Ca}^{2+}$ transient and GABA release, where it recovers the initial part of the $\left[\mathrm{Ca}^{2+}\right]$ transient. However, PV also acts more slowly to release previously bound $\mathrm{Ca}^{2+}$ as a way to sustain pre-synaptic $\left[\mathrm{Ca}^{2+}\right]$ during high-frequency action potential firing. In this way, 
GABA release is sustained by the terminals even between burst firing of the stellate and basket cells [25].

Whether the PMCA and NCX make a physiological contribution to $\mathrm{Ca}^{2+}$ recovery mechanisms at the basket cell to PN synapse is not known, although both proteins are present $[16,17]$. The very fast decay of action potentialevoked $\left[\mathrm{Ca}^{2+}\right]$ transients in basket cell axon varicosities under conditions of minimal $\mathrm{Ca}^{2+}$ buffering (from the $\mathrm{Ca}^{2+}$ indicator) predicts that a highly active and efficient $\mathrm{Ca}^{2+}$ extrusion [65] mechanism is at work.

Post-synaptic $\mathrm{Ca}^{2+}$ Control Mechanisms

Climbing Fiber Post-synapse: CF Stimulation Leads to a Very Large Post-synaptic Dendritic $\left[\mathrm{Ca}^{2+}\right]$ Signal that is Heavily Influenced by a Variety of $\mathrm{Ca}^{2+}$ Regulatory Mechanisms

The fail-safe behaviour of the pre-synaptic $\mathrm{Ca}^{2+}$ dynamics at this synapse (see "Excitatory CF Pre-synapse: Where $\mathrm{Ca}^{2+}$ Dynamics in the Pre-synapse are Dominated by $\mathrm{Ca}^{2+}$ Influx to Ensure Reliable Transmission" above) is repeated at its post-synapse. The massive and distributed glutamate release associated with activation of the CF causes an exceptionally powerful post-synaptic response known as the complex spike [72]. The complex spike is a large, active depolarizing response triggered by the AMPA receptor-mediated postsynaptic CF current. This large depolarization triggers a burst of fast action potentials generated by somatic and axonal sodium channels [73] and involves the activation of VGCC in the dendrites $[74,75]$, although the latter are not critical for the electrical appearance of the complex spike at the level of the axon and cell body [73] their activity is required for a dendritic $\mathrm{Ca}^{2+}$ signal such as required during PN synapse plasticity (see Finch and Augustine this issue]. Morphologically, the CF pre-synaptic terminal is restricted to the proximal portion of the PN dendrite [76], but the complex spike spreads electrotonically into distal dendrites and activates VGCC in spines, too [77-79]. More recently, a contribution from glutamate NMDA receptor-mediated postsynaptic $\mathrm{Ca}^{2+}$ influx to the $\mathrm{CF}$ response was identified in more mature PNs $[80,81]$.

The $\left[\mathrm{Ca}^{2+}\right]$ rise associated with a complex spike has been quantified in several studies. Taking into account the kinetics of the different fluorescent $\left[\mathrm{Ca}^{2+}\right]$ indicators used $[74,77]$, peak amplitudes of the complex spike $\left[\mathrm{Ca}^{2+}\right]$ transient tend to be larger in spines $(\sim 400 \mathrm{nM})$ as compared to dendritic shafts $(\sim 200 \mathrm{nM})$. The rising phase of this transient is determined by the duration of the depolarizing response (20-50 ms), while $\mathrm{Ca}^{2+}$ buffers and extrusion mechanisms determine the bi-exponential decay time course of the $\mathrm{Ca}^{2+}$ signal (20-30 ms and $120-150 \mathrm{~ms}$ ) that is only slightly faster in spines compared with dendritic shafts [77]. Furthermore, calbindin, the fastest among the PN main buffers, acts as a shuttle for $\mathrm{Ca}^{2+}$ transfer between the spines and dendrite [82].

Given the large $\mathrm{CF}$ stimulated $\left[\mathrm{Ca}^{2+}\right]$ rise, it is not surprising that PNs have a very high capacity to buffer $\mathrm{Ca}^{2+}$, both in their soma and dendrites. The PN's capacity to buffer $\left[\mathrm{Ca}^{2+}\right]$ increases with developmental age as the expression levels of endogenous $\mathrm{Ca}^{2+}$ buffers increases [1]. Studies to remove calbindin and parvalbumin showed that, together, these slower $\mathrm{Ca}^{2+}$ buffers influence both the peak and the biphasic decay of the $\mathrm{CF}$-induced $\left[\mathrm{Ca}^{2+}\right]$ transient in PNs [77]. Removal of both $\mathrm{Ca}^{2+}$-binding proteins allowed peak $\mathrm{Ca}^{2+}$ to rise higher and remain elevated for longer. Individually, it is calbindin that exerts most influence on the peak and early phase of the $\left[\mathrm{Ca}^{2+}\right]$ transient, whereas parvalbumin, with its slower kinetics, has a greater influence on the slower phase of $\mathrm{Ca}^{2+}$ recovery. Furthermore, removal of these important endogenous $\mathrm{Ca}^{2+}$ buffers influences the firing behaviour of the PNs; in two separate studies on knockout of calbindin and knockout of calretinin, the most significant effect was an increase in the frequency of simple spike fast firing and a reduced duration and post-spike pause of the complex spike [83, 54].

$\mathrm{Ca}^{2+}$ buffers, while very effective at limiting $\left[\mathrm{Ca}^{2+}\right]$ rises during brief periods of large $\mathrm{Ca}^{2+}$ influx, will saturate during large and longer lasting periods of $\mathrm{Ca}^{2+}$ influx. Under these conditions, it is only the active extrusion of $\mathrm{Ca}^{2+}$ from the cytosol that can maintain $\left[\mathrm{Ca}^{2+}\right]$ homeostasis, although active extrusion by PMCA and NCX does still influence the shape of short-lasting $\left[\mathrm{Ca}^{2+}\right]$ transients. The first indication of this came from an elegant and controlled study using pharmacological tools to block extrusion mechanisms [34]. When the PN was stimulated with a large $\left[\mathrm{Ca}^{2+}\right]$ load, both PMCA and NCX contributed to the decay of the $\mathrm{Ca}^{2+}$ transient: the pump by about $6 \%$ and the exchanger around $18 \%$. More recently, in PMCA2 heterozygous knockout mice, where PMCA2 expression in the cerebellum is reduced by half, we observed a doubling of the recovery time of the $\left[\mathrm{Ca}^{2+}\right]$ transient in the PN dendrite. This greater involvement of PMCA2 in the dendrite than expected from the earlier measurements from the cell body reflects the larger $\mathrm{Ca}^{2+}$ channel density and the larger surface to volume ratio of the PN dendrites (compared with the soma) [84]. Since PMCA pump activity is also under control of the biochemical environment [85], its role in the PN dendrites may have consequences for post-synaptic PN plasticity under certain conditions.

The post-synaptic $\mathrm{CF}$-induced $\mathrm{Ca}^{2+}$ transients are also amplified by the release of $\mathrm{Ca}^{2+}$ from RyR-sensitive intracellular stores [40] and perhaps also by $\mathrm{InsP}_{3}$-mediated rises in intracellular $\left[\mathrm{Ca}^{2+}\right]$ following mGluR activation ([86] but see [36]). While the high density of fast-activating (and inactivating) $\mathrm{P} / \mathrm{Q}$ channels in the $\mathrm{PN}$ dendrite provides 
for the initial fast depolarisation of the dendrite and the accompanying fast rise in $\left[\mathrm{Ca}^{2+}\right]$ during the complex spike, it is the slower propagation of the $\mathrm{CF}\left[\mathrm{Ca}^{2+}\right]$ signal throughout the PN dendrite [87] that utilises the slower release of $\mathrm{Ca}^{2+}$ from the intracellular stores. Indeed, the stores, their fill state, and the type of release may even provide for heterogeneity or compartmentalisation of the $\mathrm{CF}$-induced $\mathrm{Ca}^{2+}$ signal between dendrites and even within individual compartments of the same dendrites.

\section{PF Post-Synapse: Here, the Small Unitary EPSPs Need}

Both Spatial and Temporal Summation to Engage VGCCs and mGluRs to Amplify the $\mathrm{Ca}^{2+}$ Response via $\mathrm{Ca}^{2+}$ Release from Intracellular Stores

Single PF-PC synapses produce small excitatory postsynaptic potentials (EPSPs) $(\sim 2 \mathrm{mV})$ [88] that are insufficient to significantly activate VGCC. Only when a significant number of PFs are activated together can spatial summation lead to EPSPs large enough to activate VGCC and $\mathrm{Ca}^{2+}$ influx [89]. Modelling indicates that P-type channels are important for the amplification of spontaneous unsynchronized excitatory synaptic inputs to the PN distal dendrite [90]. More recently, a contribution from T-type currents to PF-PN dendrite/spine excitability and their $\mathrm{Ca}^{2+}$ dynamics has been revealed using both pharmacology [88] and genetic deletion of Cav 3.1 channels [91].

Early work indicated that responses to exogenously applied glutamate or an agonist of mGluR-evoked large $\left[\mathrm{Ca}^{2+}\right]$ rises in $\mathrm{PN}$ dendrites. These $\mathrm{Ca}^{2+}$ transients persisted in the absence of extracellular $\mathrm{Ca}^{2+}$, suggesting that their source was an intracellular $\mathrm{Ca}^{2+}$ store $[92,93]$. Repetitive stimulation of PFs causes glutamate release and activation of mGluR1 receptors to initiate a slow depolarisation and mobilisation of $\mathrm{Ca}^{2+}$ from internal stores via rises in $\mathrm{InsP}_{3}$ [94-96]. Furthermore, since the PF-mediated $\mathrm{Ca}^{2+}$ rise in single spines is rather restricted [95], a close apposition of a $\mathrm{Ca}^{2+}$ efflux mechanism with this $\mathrm{Ca}^{2+}$ amplification mechanism is suggested. Indeed, mGluR1, the scaffold protein Homer3 and $\mathrm{InsP}_{3}$ receptors together form a complex with PMCA2 [97], while T-type $\mathrm{Ca}^{2+}$ channels are modulated by co-localized mGluR1 at PF post-synapses [91].

\section{Inhibitory Post-synapse: Strong Post-synaptic Inhibition Shunts Post-synaptic VGCC Activation to Help Control PN Output}

The large inhibitory synaptic input from the stellate and basket cells provides a modifying influence on the excitability of the dendrites of the PN. Stimulation of the molecular layer to activate feed-forward inhibition simultaneous with $\mathrm{CF}$ activation leads to a reduction in the $\mathrm{CF}$ induced $\left[\mathrm{Ca}^{2+}\right]$ transient in the dendrites and a curtailment of the $\mathrm{Ca}^{2+}$ spike [98]. The strength and timing of this feedforward inhibition is necessary to control the precision of PN spike timing and is also sufficient to reduce the effectiveness of summation of excitatory synaptic inputs [99] presumably because the membrane becomes shunted. Modeling also predicts the importance of feed-forward inhibition for the integration of asynchronous synaptic activity in the PN dendrite [90].

\section{Concluding Remarks}

Although clearly not completely comprehensive, we hope that this review has highlighted how synaptic transmission to PNs relies on a multitude of complex and interacting $\mathrm{Ca}^{2+}$ regulatory mechanisms. The different PN synapses use diverse mechanisms within their pre- and post-synaptic compartments in order to generate $\mathrm{Ca}^{2+}$ signals that are specialized for specific modes of neurotransmitter release and post-synaptic PN behaviour. Furthermore, these mechanisms can operate in different modes in response to alterations in the $\left[\mathrm{Ca}^{2+}\right]$ within the compartment. The resulting calcium dynamics will in turn be influenced by the timing of the electrical activity that initially triggered the $\mathrm{Ca}^{2+}$ rise, by the physical geometry, and by the combination of molecular components within the very different pre- and post-synaptic compartments. As we have seen, significant advances in fluorescence based $\left[\mathrm{Ca}^{2+}\right]$ measurement technology has revealed rather precise contributions from a number of regulatory mechanisms, but remaining contributors await investigation before a full picture can emerge. Furthermore, the interaction of the $\mathrm{Ca}^{2+}$ regulatory mechanisms brings another level of complexity as compared to the properties of each mechanism in isolation, and this particular challenge will benefit from the development and application of computational models to quantitative physiological data. The importance of the interaction of $\left[\mathrm{Ca}^{2+}\right]$ regulation mechanisms at PN synapses is highlighted by the fact that removal of even one component of the $\mathrm{Ca}^{2+}$ toolkit has deleterious consequences for cerebellar function, such as loss of motor coordination. To help solve this complex puzzle, genetic modification or deletion of the individual pieces of the $\mathrm{Ca}^{2+}$ toolkit will continue to provide a powerful approach. With its variety of synaptic inputs all geared to one important output and the emergence of PN-specific knockout technology, the PN will continue to provide an excellent model to improve our understanding of how $\mathrm{Ca}^{2+}$ regulatory mechanisms influence neuronal function.

Acknowledgements We thank Amelie Peron for the useful comments on the manuscript and artwork. We acknowledge support from the Neurological Foundation New Zealand (RME) and RIKEN intramural funding (TK). 
Conflict of interest The authors declare no conflict of interest with respect to this article.

Open Access This article is distributed under the terms of the Creative Commons Attribution Noncommercial License which permits any noncommercial use, distribution, and reproduction in any medium, provided the original author(s) and source are credited.

\section{References}

1. Fierro L, Llano I. High endogenous calcium buffering in Purkinje cells from rat cerebellar slices. J Physiol. 1996;496(Pt 3):617-25.

2. Katz B, Miledi R. Spontaneous and evoked activity of motor nerve endings in calcium Ringer. J Physiol. 1969;203:689-706.

3. Hartmann J, Konnerth A. Determinants of postsynaptic $\mathrm{Ca}^{2+}$ signaling in Purkinje neurons. Cell Calcium. 2005;37:459-66.

4. Dolphin AC. Calcium channel diversity: multiple roles of calcium channel subunits. Curr Opin Neurobiol. 2009;19:237-44.

5. Llinas R, Sugimori M, Lin JW, Cherksey B. Blocking and isolation of a calcium channel from neurons in mammals and cephalopods utilizing a toxin fraction (FTX) from funnel-web spider poison. Proc Natl Acad Sci U S A. 1989;86:1689-93.

6. Usowicz MM, Sugimori M, Cherksey B, Llinas R. P-type calcium channels in the somata and dendrites of adult cerebellar Purkinje cells. Neuron. 1992;9:1185-99.

7. Kulik A, Nakadate K, Hagiwara A, et al. Immunocytochemical localization of the alpha $1 \mathrm{~A}$ subunit of the P/Q-type calcium channel in the rat cerebellum. Eur J Neurosci. 2004;19: 2169-78.

8. Regan LJ. Voltage-dependent calcium currents in Purkinje cells from rat cerebellar vermis. J Neurosci. 1991;11:2259-69.

9. Meacham CA, White LD, Barone Jr S, Shafer TJ. Ontogeny of voltage-sensitive calcium channel alpha(1A) and alpha(1E) subunit expression and synaptic function in rat central nervous system. Brain Res Dev Brain Res. 2003;142:47-65.

10. Cavelier P, Lohof AM, Lonchamp E, Beekenkamp H, Mariani J, Bossu JL. Participation of low-threshold $\mathrm{Ca}^{2+}$ spike in the Purkinje cells complex spike. NeuroReport. 2008;19:299-303.

11. Lee A, Wong ST, Gallagher D, et al. $\mathrm{Ca}^{2+} /$ calmodulin binds to and modulates P/Q-type calcium channels. Nature. 1999;399: 155-9.

12. Filoteo AG, Elwess NL, Enyedi A, Caride A, Aung HH, Penniston JT. Plasma membrane $\mathrm{Ca}^{2+}$ pump in rat brain. Patterns of alternative splices seen by isoform-specific antibodies. J Biol Chem. 1997;272:23741-7.

13. Hillman DE, Chen S, Bing R, Penniston JT, Llinas R. Ultrastructural localization of the plasmalemmal calcium pump in cerebellar neurons. Neuroscience. 1996;72:315-24.

14. Elwess NL, Filoteo AG, Enyedi A, Penniston JT. Plasma membrane $\mathrm{Ca}^{2+}$ pump isoforms $2 \mathrm{a}$ and $2 \mathrm{~b}$ are unusually responsive to calmodulin and $\mathrm{Ca}^{2+}$. J Biol Chem. 1997;272:17981-6.

15. Caride AJ, Filoteo AG, Penheiter AR, Paszty K, Enyedi A, Penniston JT. Delayed activation of the plasma membrane calcium pump by a sudden increase in $\mathrm{Ca}^{2+}$ : fast pumps reside in fast cells. Cell Calcium. 2001;30:49-57.

16. Burette AC, Strehler EE, Weinberg RJ. "Fast" plasma membrane calcium pump PMCA2a concentrates in GABAergic terminals in the adult rat brain. J Comp Neurol. 2009;512:500-13.

17. Canitano A, Papa M, Boscia F, et al. Brain distribution of the $\mathrm{Na}^{+} /$ $\mathrm{Ca}^{2+}$ exchanger-encoding genes NCX1, NCX2, and NCX3 and their related proteins in the central nervous system. Ann N Y Acad Sci. 2002;976:394-404.
18. DiPolo R, Beauge L. Asymmetrical properties of the $\mathrm{Na}-\mathrm{Ca}$ exchanger in voltage-clamped, internally dialyzed squid axons under symmetrical ionic conditions. J Gen Physiol. 1990;95: 819-35.

19. Blaustein MP, Lederer WJ. Sodium/calcium exchange: its physiological implications. Physiol Rev. 1999;79:763-854.

20. Altimimi HF, Schnetkamp PP. Examining $\mathrm{Ca}^{2+}$ extrusion of $\mathrm{Na}^{+} /$ $\mathrm{Ca}^{2+}-\mathrm{K}^{+}$exchangers. Ann N Y Acad Sci. 2007;1099:29-33.

21. Kiedrowski L, Czyz A, Baranauskas G, Li XF, Lytton J. Differential contribution of plasmalemmal $\mathrm{Na} / \mathrm{Ca}$ exchange isoforms to sodium-dependent calcium influx and NMDA excitotoxicity in depolarized neurons. J Neurochem. 2004;90:117-28.

22. de Talamoni N, Smith CA, Wasserman RH, Beltramino C, Fullmer CS, Penniston JT. Immunocytochemical localization of the plasma membrane calcium pump, calbindin-D28k, and parvalbumin in Purkinje cells of avian and mammalian cerebellum. Proc Natl Acad Sci U S A. 1993;90:11949-53.

23. Bastianelli E. Distribution of calcium-binding proteins in the cerebellum. Cerebellum. 2003;2:242-62.

24. Schwaller B, Meyer M, Schiffmann S. 'New' functions for 'old' proteins: the role of the calcium-binding proteins calbindin D$28 \mathrm{k}$, calretinin and parvalbumin, in cerebellar physiology. Studies with knockout mice. Cerebellum. 2002;1:241-58.

25. Collin T, Chat M, Lucas MG, et al. Developmental changes in parvalbumin regulate presynaptic $\mathrm{Ca}^{2+}$ signaling. $\mathrm{J}$ Neurosci. 2005;25:96-107.

26. Kishimoto J, Tsuchiya T, Cox H, Emson PC, Nakayama Y. Agerelated changes of calbindin-D28k, calretinin, and parvalbumin mRNAs in the hamster brain. Neurobiol Aging. 1998;19:77-82.

27. Vig PJ, Subramony SH, Burright EN, et al. Reduced immunoreactivity to calcium-binding proteins in Purkinje cells precedes onset of ataxia in spinocerebellar ataxia-1 transgenic mice. Neurology. 1998;50:106-13.

28. Volpe P, Villa A, Damiani E, et al. Heterogeneity of microsomal $\mathrm{Ca}^{2+}$ stores in chicken Purkinje neurons. EMBO J. 1991;10:3183-9.

29. Forge V, Mintz E, Guillain F. $\mathrm{Ca}^{2+}$ binding to sarcoplasmic reticulum ATPase revisited. II. Equilibrium and kinetic evidence for a two-route mechanism. J Biol Chem. 1993;268:10961-8.

30. Miller KK, Verma A, Snyder SH, Ross CA. Localization of an endoplasmic reticulum calcium ATPase mRNA in rat brain by in situ hybridization. Neuroscience. 1991;43:1-9.

31. Sepulveda MR, Hidalgo-Sanchez M, Mata AM. Localization of endoplasmic reticulum and plasma membrane $\mathrm{Ca}^{2+}$-ATPases in subcellular fractions and sections of pig cerebellum. Eur J Neurosci. 2004;19:542-51.

32. Chandrasekera PC, Kargacin ME, Deans JP, Lytton J. Determination of apparent calcium affinity for endogenously expressed human sarco(endo)plasmic reticulum calcium-ATPase isoform SERCA3. Am J Physiol Cell Physiol. 2009;296:C1105-14.

33. Baba-Aissa F, Raeymaekers L, Wuytack F, et al. Purkinje neurons express the SERCA3 isoform of the organellar type $\mathrm{Ca}(2+)$ transport ATPase. Brain Res Mol Brain Res. 1996;41:169-74.

34. Fierro L, DiPolo R, Llano I. Intracellular calcium clearance in Purkinje cell somata from rat cerebellar slices. J Physiol. 1998;510 (Pt 2):499-512.

35. Mateos JM, Benitez R, Elezgarai I, et al. Immunolocalization of the mGluR1b splice variant of the metabotropic glutamate receptor 1 at parallel fiber-Purkinje cell synapses in the rat cerebellar cortex. J Neurochem. 2000;74:1301-9.

36. Reichelt W, Knöpfel T. Glutamate uptake controls expression of a slow postsynaptic current mediated by mGluRs in cerebellar Purkinje cells. J Neurophysiol. 2002;87:1974-80.

37. Kuwajima G, Futatsugi A, Niinobe M, Nakanishi S, Mikoshiba K. Two types of ryanodine receptors in mouse brain: skeletal muscle type exclusively in Purkinje cells and cardiac muscle type in various neurons. Neuron. 1992;9:1133-42. 
38. Lai FA, Dent M, Wickenden C, et al. Expression of a cardiac $\mathrm{Ca}(2$ + )-release channel isoform in mammalian brain. Biochem $\mathrm{J}$. 1992;288(Pt 2):553-64.

39. Sorrentino V, Volpe P. Ryanodine receptors: how many, where and why? Trends Pharmacol Sci. 1993;14:98-103.

40. Kano M, Garaschuk O, Verkhratsky A, Konnerth A. Ryanodine receptor-mediated intracellular calcium release in rat cerebellar Purkinje neurones. J Physiol. 1995;487(Pt 1):1-16.

41. Ross CA, Meldolesi J, Milner TA, Satoh T, Supattapone S, Snyder SH. Inositol 1, 4, 5-trisphosphate receptor localized to endoplasmic reticulum in cerebellar Purkinje neurons. Nature. 1989;339:468-70.

42. De Smedt H, Missiaen L, Parys JB, et al. Determination of relative amounts of inositol trisphosphate receptor mRNA isoforms by ratio polymerase chain reaction. J Biol Chem. 1994;269:21691-8.

43. Khodakhah K, Armstrong CM. Inositol trisphosphate and ryanodine receptors share a common functional $\mathrm{Ca}^{2+}$ pool in cerebellar Purkinje neurons. Biophys J. 1997;73:3349-57.

44. Matsumoto M, Kato K. Altered calcium dynamics in cultured cerebellar cells from IP3R1-deficient mice. NeuroReport. 2001;12:3471-4.

45. Mintz IM, Sabatini BL, Regehr WG. Calcium control of transmitter release at a cerebellar synapse. Neuron. 1995;15:675-88.

46. Wu LG, Saggau P. Presynaptic inhibition of elicited neurotransmitter release. Trends Neurosci. 1997;20:204-12.

47. Doroshenko PA, Woppmann A, Miljanich G, Augustine GJ. Pharmacologically distinct presynaptic calcium channels in cerebellar excitatory and inhibitory synapses. Neuropharmacology. 1997;36:865-72.

48. Atluri PP, Regehr WG. Determinants of the time course of facilitation at the granule cell to Purkinje cell synapse. J Neurosci. 1996;16:5661-71.

49. Takahashi KA, Linden DJ. Cannabinoid receptor modulation of synapses received by cerebellar Purkinje cells. J Neurophysiol. 2000;83:1167-80.

50. Pekhletski R, Gerlai R, Overstreet LS, et al. Impaired cerebellar synaptic plasticity and motor performance in mice lacking the mGluR4 subtype of metabotropic glutamate receptor. J Neurosci. 1996;16:6364-73.

51. Empson RM, Garside ML, Knöpfel T. Plasma membrane $\mathrm{Ca}^{2+}$ ATPase 2 contributes to short-term synapse plasticity at the parallel fiber to Purkinje neuron synapse. J Neurosci. 2007;27:3753-8.

52. Sabatini BL, Oertner TG, Svoboda K. The life cycle of $\mathrm{Ca}(2+)$ ions in dendritic spines. Neuron. 2002;33:439-52.

53. Regehr WG, Atluri PP. Calcium transients in cerebellar granule cell presynaptic terminals. Biophys J. 1995;68:2156-70.

54. Schiffmann SN, Cheron G, Lohof A, et al. Impaired motor coordination and Purkinje cell excitability in mice lacking calretinin. Proc Natl Acad Sci U S A. 1999;96:5257-62.

55. Brenowitz SD, Regehr WG. Reliability and heterogeneity of calcium signaling at single presynaptic boutons of cerebellar granule cells. J Neurosci. 2007;27:7888-98.

56. Zhang W, Linden DJ. Neuromodulation at single presynaptic boutons of cerebellar parallel fibers is determined by bouton size and basal action potential-evoked $\mathrm{Ca}$ transient amplitude. J Neurosci. 2009;29:15586-94.

57. Regehr WG. Interplay between sodium and calcium dynamics in granule cell presynaptic terminals. Biophys J. 1997;73:2476-88.

58. Carter AG, Vogt KE, Foster KA, Regehr WG. Assessing the role of calcium-induced calcium release in short-term presynaptic plasticity at excitatory central synapses. J Neurosci. 2002;22:21-8.

59. Crepel F, Daniel H. Developmental changes in agonist-induced retrograde signaling at parallel fiber-Purkinje cell synapses: role of calcium-induced calcium release. J Neurophysiol. 2007;98:2550-65.

60. Hashimoto K, Kano M. Presynaptic origin of paired-pulse depression at climbing fibre-Purkinje cell synapses in the rat cerebellum. J Physiol. 1998;506(Pt 2):391-405.
61. Regehr WG, Mintz IM. Participation of multiple calcium channel types in transmission at single climbing fiber to Purkinje cell synapses. Neuron. 1994;12:605-13.

62. Borst JG, Sakmann B. Facilitation of presynaptic calcium currents in the rat brainstem. J Physiol. 1998;513(Pt 1):149-55.

63. Vincent P, Marty A. Fluctuations of inhibitory postsynaptic currents in Purkinje cells from rat cerebellar slices. J Physiol. 1996;494(Pt 1):183-99.

64. Stephens GJ, Morris NP, Fyffe RE, Robertson B. Cav2.1/alpha1A (P/Q-type) voltage-dependent calcium channel mediates inhibitory neurotransmission onto mouse cerebellar Purkinje cells. Eur J Neurosci. 2001;13:1902-12.

65. Conti R, Tan YP, Llano I. Action potential-evoked and ryanodinesensitive spontaneous $\mathrm{Ca}^{2+}$ transients at the presynaptic terminal of a developing CNS inhibitory synapse. J Neurosci. 2004;24:6946-57.

66. Christie JM, Jahr CE. Dendritic NMDA receptors activate axonal calcium channels. Neuron. 2008;60:298-307.

67. Rusakov DA, Saitow F, Lehre KP, Konishi S. Modulation of presynaptic $\mathrm{Ca}^{2+}$ entry by AMPA receptors at individual GABAergic synapses in the cerebellum. J Neurosci. 2005;25:4930-40.

68. Llano I, Gonzalez J, Caputo C, et al. Presynaptic calcium stores underlie large-amplitude miniature IPSCs and spontaneous calcium transients. Nat Neurosci. 2000;3:1256-65.

69. Stephens GJ. G-protein-coupled-receptor-mediated presynaptic inhibition in the cerebellum. Trends Pharmacol Sci. 2009;30:421-30.

70. Duguid IC, Smart TG. Retrograde activation of presynaptic NMDA receptors enhances GABA release at cerebellar interneuron-Purkinje cell synapses. Nat Neurosci. 2004;7:525-33.

71. Caillard O, Moreno H, Schwaller B, Llano I, Celio MR, Marty A. Role of the calcium-binding protein parvalbumin in short-term synaptic plasticity. Proc Natl Acad Sci U S A. 2000;97:13372-7.

72. Eccles JC, Llinas R, Sasaki K. The excitatory synaptic action of climbing fibres on the Purkinje cells of the cerebellum. J Physiol. 1966;182:268-96.

73. Davie JT, Clark BA, Hausser M. The origin of the complex spike in cerebellar Purkinje cells. J Neurosci. 2008;28:7599-609.

74. Knöpfel T, Vranesic I, Staub C, Gahwiler BH. Climbing fibre responses in olivo-cerebellar slice cultures. II. Dynamics of cytosolic calcium in Purkinje cells. Eur J Neurosci. 1991;3:343-8.

75. Ross WN, Werman R. Mapping calcium transients in the dendrites of Purkinje cells from the guinea-pig cerebellum in vitro. J Physiol. 1987;389:319-36.

76. Strata P, Rossi F. Plasticity of the olivocerebellar pathway. Trends Neurosci. 1998;21:407-13.

77. Schmidt H, Stiefel KM, Racay P, Schwaller B, Eilers J. Mutational analysis of dendritic $\mathrm{Ca}^{2+}$ kinetics in rodent Purkinje cells: role of parvalbumin and calbindin D28k. J Physiol. 2003;551:13-32.

78. Miyakawa H, Lev-Ram V, Lasser-Ross N, Ross WN. Calcium transients evoked by climbing fiber and parallel fiber synaptic inputs in guinea pig cerebellar Purkinje neurons. J Neurophysiol. 1992;68:1178-89.

79. Llinas R, Sugimori M. Electrophysiological properties of in vitro Purkinje cell dendrites in mammalian cerebellar slices. J Physiol. 1980;305:197-213.

80. Piochon C, Irinopoulou T, Brusciano D, Bailly Y, Mariani J, Levenes C. NMDA receptor contribution to the climbing fiber response in the adult mouse Purkinje cell. J Neurosci. 2007;27:10797-809.

81. Renzi M, Farrant M, Cull-Candy SG. Climbing-fibre activation of NMDA receptors in Purkinje cells of adult mice. J Physiol. 2007;585:91-101.

82. Schmidt H, Eilers J. Spine neck geometry determines spinodendritic cross-talk in the presence of mobile endogenous calcium binding proteins. J Comput Neurosci. 2009;27:229-43.

83. Servais L, Bearzatto B, Schwaller B, et al. Mono- and dualfrequency fast cerebellar oscillation in mice lacking parvalbumin and/or calbindin D-28 k. Eur J Neurosci. 2005;22:861-70. 
84. Empson RM, Turner PR, Nagaraja RY, Beesley PW, Knöpfel T. Reduced PMCA2 expression slows calcium dynamics in mouse cerebellar Purkinje neurons and alters the precision of motor coordination. J Physiol 2010;588:907-922.

85. Ferragamo MJ, Reinardy JL, Thayer SA. $\mathrm{Ca}^{2+}$-dependent, stimulus-specific modulation of the plasma membrane $\mathrm{Ca}^{2+}$ pump in hippocampal neurons. J Neurophysiol. 2009;101: 2563-71.

86. Dzubay JA, Otis TS. Climbing fiber activation of metabotropic glutamate receptors on cerebellar purkinje neurons. Neuron. 2002;36:1159-67.

87. Yuan Q, Qiu DL, Weber JT, Hansel C, Knöpfel T. Climbing fibertriggered metabotropic slow potentials enhance dendritic calcium transients and simple spike firing in cerebellar Purkinje cells. Mol Cell Neurosci. 2007;35:596-603.

88. Isope P, Barbour B. Properties of unitary granule cell $\rightarrow$ Purkinje cell synapses in adult rat cerebellar slices. J Neurosci. 2002;22: 9668-78.

89. Eilers J, Augustine GJ, Konnerth A. Subthreshold synaptic $\mathrm{Ca}^{2+}$ signalling in fine dendrites and spines of cerebellar Purkinje neurons. Nature. 1995;373:155-8.

90. De Schutter E. Dendritic voltage and calcium-gated channels amplify the variability of postsynaptic responses in a Purkinje cell model. J Neurophysiol. 1998;80:504-19.

91. Hildebrand ME, Isope P, Miyazaki T, et al. Functional coupling between mGluR1 and Cav3.1 T-type calcium channels contributes to parallel fiber-induced fast calcium signaling within Purkinje cell dendritic spines. J Neurosci. 2009;29:9668-82.

92. Llano I, Dreessen J, Kano M, Konnerth A. Intradendritic release of calcium induced by glutamate in cerebellar Purkinje cells. Neuron. 1991;7:577-83.

93. Vranesic I, Batchelor A, Gahwiler BH, Garthwaite J, Staub C, Knöpfel T. Trans-ACPD-induced $\mathrm{Ca}^{2+}$ signals in cerebellar Purkinje cells. NeuroReport. 1991;2:759-62.

94. Batchelor AM, Knöpfel T, Gasparini F, Garthwaite J. Pharmacological characterization of synaptic transmission through mGluRs in rat cerebellar slices. Neuropharmacology. 1997; 36:401-3.

95. Finch EA, Augustine GJ. Local calcium signalling by inositol-1, 4, 5 trisphosphate in Purkinje cell dendrites. Nature. 1998;396:753-6.

96. Takechi H, Eilers J, Konnerth A. A new class of synaptic response involving calcium release in dendritic spines. Nature. 1998; 396:757-60.

97. Kurnellas MP, Lee AK, Li H, Deng L, Ehrlich DJ, Elkabes S. Molecular alterations in the cerebellum of the plasma membrane calcium ATPase 2 (PMCA2)-null mouse indicate abnormalities in Purkinje neurons. Mol Cell Neurosci. 2007;34:178-88.

98. Callaway JC, Lasser-Ross N, Ross WN. IPSPs strongly inhibit climbing fiber-activated $\left[\mathrm{Ca}^{2+}\right] \mathrm{i}$ increases in the dendrites of cerebellar Purkinje neurons. J Neurosci. 1995;15:2777-87.

99. Mittmann W, Häusser M. Linking synaptic plasticity and spike output at excitatory and inhibitory synapses onto cerebellar Purkinje cells. J Neurosci. 2007;27:5559-70. 